\title{
Utilizing E-Business Technologies in Supply Chains: The Impact of Firm Characteristics and Teams
}

\author{
P. Fraser Johnson*a \\ The University of Western Ontario \\ Robert D. Klassen $^{\text {a }}$ \\ The University of Western Ontario \\ Michiel R. Leenders ${ }^{\text {a }}$ \\ The University of Western Ontario \\ Amrou Awaysheh ${ }^{\mathrm{a}}$ \\ The University of Western Ontario \\ ${ }^{a}$ Richard Ivey School of Business, The University of Western Ontario, London, Ontario, Canada N6A $3 K 7$
}

\begin{abstract}
This paper presents findings from an exploratory study that analyzes the drivers and outcomes of e-business technology use in the supply chain. Using a combination of case studies and survey data from a diverse sample of industries, the research examines how industry context, firm characteristics and firm-level strategic resources, such as purchasing teams, influence the exploitation of e-business technologies and the relationship between e-business technology use and firm performance. Based on a synthesis of related literatures from transaction cost economics and the relational view of the supply chain, a two-dimensional framework for ebusiness technology is proposed with transactional and relational dimensions. However, empirical analysis indicated that transactional technologies can be further subdivided into two factors: dyadic cooperation and price determination. Significant differences were found between the two dimensions in terms of their overall levels of adoption, with dyadic coordination being the most widely adopted. In addition, the development of strategic resources expanded, in particular internal and customer teams, the use of e-business technologies expanded. Purchasing organizational structure and firm size also were positively related to the adoption of transactional e-business technologies. Finally, of particular importance to practitioners, e-business technologies targeted at reducing dyadic coordination costs lead to improved financial performance.
\end{abstract}

Key Words: e-business, purchasing, teams, supply chain management, firm performance, resource based view, relational view, transaction cost economics.

\footnotetext{
Corresponding author

$*$

Richard Ivey School of Business, The University of Western Ontario, London, Ontario, Canada N6A $3 K 7$ email: fjohnson@ivey.uwo.ca, tel.: (519) 661-3219, fax: (519) 661-3485
}

This is the authors' manuscript published in final form as:

Johnson, P. F., Klassen, R. D., Leenders, M. R., \& Awaysheh, A. (2007). Utilizing e-business technologies in supply chains: The impact of firm characteristics and teams. Journal of Operations Management, 25(6), 1255-1274. https://doi.org/10.1016/j.jom.2007.01.005 


\title{
Utilizing E-Business Technologies in Supply Chains: The Impact of Firm Characteristics and Teams
}

\begin{abstract}
This paper presents findings from an exploratory study that analyzes the drivers and outcomes of e-business technology use in the supply chain. Using a combination of case studies and survey data from a broad sample of industries, the research examines how industry context, firm characteristics and firm-level strategic resources, such as purchasing teams, influence the exploitation of e-business technologies and the relationship between e-business technology use and firm performance. Based on a synthesis of related literatures from transaction cost economics and the relational view of the supply chain, a two-dimensional framework for ebusiness technology is proposed with transactional and relational dimensions. However, empirical analysis indicated that transactional technologies can be further subdivided into two factors: dyadic cooperation and price determination. Significant differences were found between the two dimensions in terms of their overall levels of adoption, with dyadic coordination being the most widely adopted. In addition, the development of strategic resources expanded, in particular internal and customer teams, the use of e-business technologies expanded. Purchasing organizational structure and firm size also were positively related to the adoption of transactional e-business technologies. Finally, of particular importance to practitioners, e-business technologies targeted at reducing dyadic coordination costs lead to improved financial performance.
\end{abstract}

Key Words: e-business, purchasing, teams, supply chain management, firm performance, resource based view, relational view, transaction cost economics.

\section{Introduction}

There has been substantial managerial interest in opportunities to use e-business technologies in the supply chain to create competitive advantage. The literature suggests that the potential benefits of e-business technologies include lower prices from suppliers, improved speed and flexibility, lower transaction costs, higher customer service levels and reduced investments in supply chain inventories (Neef, 2001; Essig and Arnold, 2001; Deeter-Schmelz et al., 2001). However, our understanding of how and where firms use e-business technologies, and the direct benefits that they provide, is still limited. As firms weigh opportunities to invest in new supply chain technologies and make the accompanying changes to their organizations, supply base and business processes, an improved understanding of where opportunities exist to better utilize e- 
business technologies is required.

This paper examines how firm-level strategic resources, such as purchasing teams, influence the exploitation of e-business technologies and the relationship between e-business technology use and firm performance. Underpinning this research is literature in transaction cost economics, the resource based view and the relational view. Collectively, the paper offers three primary contributions. First, an important objective is to develop a better understanding of the relationships between different, but related forms of e-business technologies. In doing so, two general dimensions are identified and empirically validated using data from four case studies and a sample of 284 large North American firms. This data also provides the basis for assessing the level of use of e-business technology in supply chain management.

Second, the research seeks to establish the relationship between the use of e-business technologies and its enablers, including related strategic resources such as purchasing teams. Research in the management information systems literature recognizes the importance of using cross-functional teams as part of successful implementation and assimilation of new information technologies (Robey et al., 2002), and purchasing teams represent a common approach to managing activities within the supply chain to achieve internal and external integration (Ellram and Pearson, 1993; Trent and Monczka, 1994; Giunipero and Vogt, 1997). This path of inquiry suggests that merely investing in e-business technologies is not sufficient to provide competitive advantage; instead, it is the capabilities to effectively implement e-business technologies within the supply chain that is more important. Consequently, the successful adoption of e-business technologies might be expected to leverage the team-based boundary spanning capabilities provided by purchasing teams.

Finally, a number of industry- and firm-level characteristics that affect the rate of 
technological change can also influence supply chain relationships, and thus, opportunities to use e-business technologies. Moreover, it is not clear what the competitive implications are for financial performance. To date, much of the research related to the benefits of e-business technology in supply chain management tends to be anecdotal, consisting of case studies. While that research has been useful in framing the potential opportunities, this research undertakes a broader assessment of firm financial performance related to the use of e-business in the supply chain.

Drawing from the transaction cost economics, the resource based view and the relational view literature, the following section defines the constructs and hypothesized relationships that underlie relationships between the proposed drivers, e-business technology use and financial performance. Next, the survey methodology and construct measurement are detailed. Finally, the results and discussion are presented, along with implications for both future research and managerial practice.

\section{Theoretical Development}

Two theoretical perspectives have become well-established as foundational for research that integrates supply chain management and e-business technologies: transaction cost economics (TCE) (e.g., Williamson, 1991) and the relational view (e.g., Dyer and Singh, 1998). These perspectives provide the basis for a framework that identifies two generic forms of e-business technology: transactional and relational technologies. These two forms, in turn, suggest a number of implications for how and why each might be adopted and resulting performance outcomes. In addition, a third perspective, the resource-based view of the firm (RBV) (Barney, 1991), offers a theoretical rationale for why some attempts to implement e-business technologies have not delivered competitive advantages. Firm-level strategic resources, such as purchasing teams, are 
likely necessary to both implement and unlock the competitive potential of e-business technologies. Teams are an instrumental aspect of organizational learning (Hult et al., 2003).

\subsection{Purchasing Teams}

A team is a group brought together to achieve a shared goal, is independent and bound and stable over time, and has the authority to manage its own work and internal processes (Alderfer, 1977; Hackman, 1990). Teams attempt to capture the benefits of cross-functional skills and orientation, and represent an accepted method for managing projects and activities in a wide variety of areas, such as quality, information systems, new product development and cost reduction initiatives. The formation and management of teams continues to present complex challenges, indicating that effective implementation is a strategic resource, possibly linked to organizational learning (Hult et al., 2003), social complexity and team-based skills, i.e., the team is greater than the sum of its members (Coff, 1999; Lewis, 2003).

The reasons for these challenges are multifold. Purchasing teams combine skills and resources of several stakeholders, which can span across multiple functions or subunits, to facilitate the timely completion of a supply management goal that will benefit the organization, such as supplier selection, standardization of purchases, reduced total cost of ownership, improved supplier quality or reduction of cycle times (Ellram and Pearson, 1993; Denison et al., 1996; Trent and Monczka, 1998). Purchasing teams usually consist of individuals from a variety of functional areas or from the purchasing function only (Trent and Monczka, 1998). Finally, teams may include representatives from outside the organization, such as suppliers or customers (Carter and Narasimhan, 1996). Such teams bring together stakeholders from the supply chain to address issues of mutual concern, such as quality problems or new product development (Dyer, 1996). The ability of firms to structure and manage long-term co-operative relationships with 
customers and suppliers, and sometimes with competitors, can influence the success of their supply chain initiative (Bechtel and Jayaram, 1997).

Firm-level adoption of purchasing teams can enhance both external and internal integration through the involvement of internal stakeholders, suppliers and/or customers (Johnson et al., 2002). Prior research has supported a two-dimensional construct: internal teams and customer teams. Internal teams consisted of purchasing councils, supplier councils, commodity teams and cross-functional teams. The common element among the four items in this construct was that they were concentrated and organized within the firm and/or the supplier aimed at reducing transaction costs. In contrast, customer teams had a strong downstream orientation, with active involvement of customers in supply chain improvement through the creation of relational-specific investments (Johnson et al. 2002).

The resource based view (RBV) proposes that firms seek to acquire and control bundles of resources that when combined become sources of competitive advantage. Strategic resources are defined as assets, capabilities and organizational processes controlled by a firm which have value, are rare, difficult to imitate and have few substitutes (Barney, 1991). A firm's resources can either be acquired in the case of tradable resources (e.g., patents) or can be path-dependent, accumulating over time (e.g., supply expertise) (Black and Boal, 1994; Dierickx and Cool, 1989).

While RBV is a widely applied perspective for studying firm strategy, it also has clear implications for internal firm structure. As noted above, firms also must have internal organizational structures, such as inter-functional teams, and business processes that enable it to acquire and leverage resources to facilitate the production and delivery of goods and services. Furthermore, firms can create competitive advantage when they are successful in creating 
linkages with critical suppliers that successfully exclude competitors from forming the same relationships (Rungtusanatham et al., 2003). This advantage may result from the resource of the team itself which is embedded in the firm, or alternatively, the firm may possess idiosyncratic characteristics that foster the development of effective teams, including those targeted at identifying, nurturing and leveraging e-business technologies.

\subsection{Transaction Cost Economics and e-Business Technologies}

At the risk of oversimplifying, TCE focuses on how a firm should organize its boundary spanning activities to minimize its combined production and transaction costs (Williamson, 1975). Bounded rationality of the firm's management and potential opportunism by supply chain partners are two key assumptions embedded in TCE that together create transaction costs between firms along the supply chain (Grover and Malhotra, 2003). Markets (e.g., outsourcing) and hierarchies (e.g., vertical integration) are proposed as competing options for balancing transaction costs relative to opportunism (Rindfleisch and Heide, 1997). In situations where the total costs of keeping transactions within the firm's governance structure are high (e.g., vertical integration), a market-based governance structure may offer competitive advantages.

Thus, TCE raises strategic issues related to the boundary of the firm (e.g., what is produced in-house versus what is outsourced and purchased) and represents one theoretical basis for explaining why firms choose to make or buy. Furthermore, the decision to buy, as opposed to make, requires the development of processes, referred to as governance structure, as a means of controlling the flow of goods and services in the supply chain, and inter-organizational relationship management capabilities with suppliers (Barringer and Harrison, 2000). Creation of teams with suppliers and/or customers represents one mechanism to manage boundary spanning activities (Johnson et al., 2002). 
TCE has been used increasingly by researchers to study supply chain management issues (e.g., Rindfleisch and Heide, 1997). Transaction costs encompass all forms of coordination costs, as well as efforts to mitigate transaction risk. Coordination costs are the cost of exchanging information and incorporating the information into decision processes. In supply chain management, coordination costs might include the costs of exchanging information related to products, price, demand and product design changes (Grover and Malhotra, 2003). In contrast, transaction risk includes the risk that other supply chain parties will shirk their agreed upon responsibilities and any asset-specific investments. For example, suppliers may ship products of inferior quality or buyers may ask for price concessions following an investment by a supplier in new equipment (Grover and Malhotra, 2003).

E-business technologies are digitally enabled inter- or intra-organizational Internet-based information technologies used to accomplish business processes (Boone and Ganeshan, 2004). E-business technologies come in a variety of forms, some well-established such as electronic data interchange (EDI), and others newly developed such as online reverse auctions.

E-business technologies represent one mechanism to manage boundary spanning activities in the supply chain under TCE. A number of e-business technologies focus specifically on reducing coordination costs (Subramani, 2004) and may also represent an asset-specific investment increasing the potential for opportunistic behavior by one party (Zaheer and Venkatraman, 1994). For example, some of these technologies represent streamlining and automating business processes among supply chain partners as a means of reducing transaction costs (Choudhury et al., 1998), such as electronic requests for quotations (eRFQ), EDI and electronic transmission of purchase orders (ePO) (Subramani, 2004). Other potential benefits of e-business technology use include the ability to share information in a timely manner as means 
of reducing transaction risk, in areas such as holding inventory, freight and administration (Srinivasan et al., 1994; Mukhopadhyay et al., 1995). Firms have been actively pursuing opportunities to automate supply chain processes to reduce transaction costs by reducing administrative costs and reducing the cycle time from need recognition to receipt of the purchased good or service (Johnson and Leenders, 2004).

Thus, TCE points to one form of e-business technology that seeks to improve existing inter-firm business processes, thereby reducing transaction costs and transaction risk. Here, these are labeled transactional technologies. It is expected that use of transactional e-business technologies requires limited customer engagement, and is heavily driven by the strategic resources offered by internal teams:

Hypothesis 1: As the use of internal teams for supply chain management increase, the use of transactional e-business technologies increases.

\subsection{The Relational View of Supply Networks and e-Business Technologies}

The relational view is a more recent perspective that has emerged from the growing literature related to trust and the benefits of relationship building to obtain mutual benefits. It proposes that a firm's critical resources may be boundary spanning and embedded in inter-firm resources, thereby representing "relational rents" (Dyer and Singh, 1998). Whereas RBV focuses on how individual firms acquire sources of competitive advantage, the relational view focuses on how partnering firms jointly generate relational rents.

One example of empirical research involving relational rents is Dyer's (1996) article Chrysler's keiretsu supplier network. He argues that the Japanese model of cooperative relationships can be a potential source of competitive advantage. Specific to e-business

technologies, recent research on reverse auctions has included assessing the implications of using this technology in established buyer-supply relationships (e.g., Beall et al., 2003). 
The relational view identifies four potential sources of inter-organizational competitive advantage: relation-specific assets, knowledge-sharing routines, complementary resources and capabilities, and effective governance (Dyer and Singh 1998). Thus, capturing relational rents requires capabilities with respect to external relationship management, potentially including the use of e-business technologies derived from buyer-supplier team-based activities.

E-business technologies can offer new approaches to sourcing and collaboration with supply chain partners, which can be exploited to create competitive advantage (Barua et al., 2004). Relational-specific investments, such as private exchanges between buyers and key suppliers, create more value than non-specialized generic assets and can be an important source of competitive advantage (Dyer and Singh, 1998). Consequently, e-business technologies used to support collaboration are labeled relational technologies.

Day's (1994) typology differentiates among transactional information systems and relational information systems. Transactional information systems, labeled inside-out and outside-in, address the need for information coordination, whereas relational information systems, labeled spanning, serve to integrate the firm with customers and suppliers.

In contrast to transactional e-business technologies, it is expected that relational ebusiness technologies are positively related to the use of customer teams because of the need for buyer-supplier collaboration.

Hypothesis 2: As the use of customer teams for supply chain management increase, the use of relational e-business technologies increases.

\subsection{E-Business Technologies and Firm Performance}

Empirical research has examined the relationship between information systems and firm performance. This literature draws a distinction between information technologies (e.g., ebusiness technologies) and information systems (e.g., combination of assets and capabilities that 
leverage the effective use of information technologies). Wade and Hulland (2004) summarize empirical information systems research and provide an overview of how RBV can be applied to examine the relationship between information systems and firm performance.

There is little consensus in the literature concerning the connection between information technology and performance (Tippins and Sohi, 2003). For example, Bharadwaj (2000) provided a framework to explain how RBV can be used to explain that information technology can be viewed as an organizational capability, and provided support that information technology capability is a rent generating resource that can provide sustained superior performance. This research also identified complementary information technology and supply chain resources as a source of competitive advantage. However, other empirical studies have provided contradictory findings, suggesting that there is no connection between information technology and performance (e.g., Powell and Dent-Micallef, 1997).

Research in supply chain management has only recently begun to examine the relationship between e-business technologies and firm performance. Early research by Mukopadhyay et al. (1995) examined the impact of EDI use, a transactional form of e-business technology, on firm performance at a large automotive manufacturer and its suppliers, and was able to estimate the financial benefits of EDI use at the company. Frohlich (2002) found that supplier and customer e-integration, which represents transactional e-business technologies, had a strong effect on e-business performance (e.g., percent of procurement and sales revenues conducted using the Internet) and operational performance (e.g., respondent perception of delivery times, transaction costs and inventory turnover). In another study, Boyer and Olson (2002) studied customers of a retailer of office supplies and found that firms that used online eprocurement tools to order through the Internet, again transactional e-business technologies, 
generally believed that the technology led to reduced costs and improved inventory accuracy.

Focusing more narrowly on technology-intensive industries, Wu et al. (2003) studied the antecedents of e-business adoption, adoption intensity and performance. Examining four business process domains, three of which are primarily transactional supply chain in nature, they found that supplier and customer communication positively affected performance outcomes, while e-procurement and online order taking did not. However, this early study was conducted in 2001 and the generally low adoption level of e-procurement may have attenuated any linkage between performance and the last two factors. Finally, Barua et al. (2004) relied on RBV to provide theoretical support for how online informational capabilities, also a form of transactional e-business technology, led to improved financial performance. This research found a significant positive effect of doing business electronically (e.g., using transactional e-business technologies) with customers upon financial performance, but no benefits on the supplier side. (Table 1 summarizes several aspects of these studies.)

Thus, research on the relationship between e-business technologies and performance has focused exclusively on transactional forms of e-business technologies, sometimes with conflicting results (e.g., Wu et al., 2003; Barua et al. 2004). For example, while there has been a great deal of interest related to electronic reverse auctions, most of this research has used casebased methodology to assess the risks of this method of sourcing and to identify appropriate circumstances for use (e.g., Katok and Roth 2004; Jap 2002). To date, little work has been reported that examines the relationship between relational e-business technologies and performance. In addition, much of the prior research has used perceptual measures of performance by users of e-business technology (e.g., Boyer and Olson, 2002; Wu et al., 2003), while the relationship between e-business technology use and financial performance has yet to be 
established.

Although the literature provides conflicting results concerning the connection between information technology use and performance, there is evidence that firms can potentially create competitive advantage, consistent with RBV, through capabilities associated with e-business technologies. Thus, we propose the following:

Hypothesis 3: As the use of e-business technologies increases, firm-level financial performance increases.

\section{Research Design}

A two-phased study employing survey- and case-based empirical methods was undertaken to understand both the relationship between the use of purchasing teams, e-business technology adoption and expected performance outcomes. These methods were complementary: survey methods, combined with archival data, provided a means to examine the generalizability of relationships. Then, by way of follow up, case-based study allowed a greater examination of the mechanisms that underpin the relationships that were statistically supported. This is particularly critical when theory is still in its formative stages (Yin, 1992). Also, this set of case studies effectively leveraged and integrated data from different sources, including interviews and archival data (Eisenhardt, 1988). In the following sections, we describe our sample, data collection procedures, and case assessment framework.

\subsection{Survey Sample}

A survey instrument was developed to examine the relationships between a firm-level strategic resource, namely purchasing team usage, and e-business technology usage. This level, rather than the SBU or plant, was chosen because the limited empirical research reported to date points to the design of e-business technologies as enabling better firm-level integration (Neef, 2001). 
The target population for this study was comprised of large manufacturing and services firms in the U.S. and Canada. The Title 1 membership list of the Institute of Supply Management (ISM) and the CAPS Research membership directory were used to identify U.S. respondents for firms on the Fortune 1000 manufacturing and services lists. The membership database of the Purchasing Management Association of Canada (PMAC) was used to identify Canadian respondents for firms on the Financial Post 100 list. In order to reduce the potential for singlerespondent bias, we focused on high-level managers who tend to be more reliable sources of information than lower-level managers (Philips, 1981). The title of the respondent sought was primarily vice president or director of purchasing or supply chain management.

The survey was nine pages in length and typically required 20 to 30 minutes to complete. The survey was pre-tested on a group of five chief purchasing officers (CPOs) and two academics. This group was asked to review the questionnaire for structure, readability, ambiguity and completeness, and the survey instrument was refined based on their feedback. Appendix A provides a summary of the relevant questions used in the survey instrument.

In an effort to increase the response rate, a modified version of the methodology of Dillman (2000) was followed. In October 2003, questionnaires were mailed along with a cover letter and stamped return envelope to 658 organizations. From the initial sample frame of 658,18 were dropped because they had been inadvertently duplicated in the database, ceased operation or moved to a new location. Consequently, the effective sample frame was 640 organizations, consisting of 562 and 78 U.S. and Canadian firms, respectively. Four waves of contact were then conducted: initial mailing of survey, reminder emails or fax to all non-respondents; second mailing of the survey; and finally, a reminder telephone call.

To encourage the widest possible participation by both users and non-users of e-business 
technologies, respondents were given three options for the completing and returning the survey: mail in the stamped return envelope; fax; and Internet (web-based questionnaire). Nearly threequarters of the responses were received via mail. Of the 640 targeted firms, 284 (44\%) completed surveys were returned. Summary statistics are provided in Table 2. In this study, nonresponse bias was tested by comparing the responses of early and late waves of returned surveys for firm size and respondent title (Armstrong and Overton, 1977). No significant differences were encountered.

\subsection{E-Business Technologies Construct}

Based on the breadth of traditional and new e-business technologies noted earlier, a dozen forms were drawn from the MIS and supply chain literatures (see Table 3). While it is undoubtedly possible to identify other forms, this list represented a workable set that spanned many applications rather than a complete inventory of all possible technologies. Respondents were requested to report the level of e-business technology usage by the firm for each e-technology on a five-point Likert scale $(1=$ none to $5=$ extensive $)$. The average usage of each of the 12 forms is reported in Table 3. Of these technologies, electronic/online purchase order system and electronic data interchange (EDI) were used most extensively. In contrast, mean usage for the six exchange/e-marketplace activities was very low, averaging much less than two, indicating little adoption of these more recent forms of e-business technologies.

As a first step toward identifying a taxonomy of e-business technologies, exploratory factor analysis (principal components analysis with varimax rotation) was used to analyze the pattern of usage for the 12 forms of e-business technologies. Both a scree plot and eigenvalue criterion (greater than one) supported the extraction of three factors. All items loaded on one factor above the recommended level of 0.50 (Hair et al., 1995). Table 4 provides the results for 
the factor analysis of e-business technology usage.

While e-business technologies were initially conceived as a two-dimensional construct, specifically transactional and relational e-business technologies, this analysis indicated that a more nuanced characterization is important. The first factor was labeled "dyadic coordination", and included electronic / online purchase order system, electronic / online supplier catalogue, real-time linkage with suppliers and electronic data interchange. The reliability coefficient (Cronbach's $\alpha$ ) for the dyadic coordination factor was 0.77 , above the threshold recommended for exploratory research (Nunnally and Berstein, 1994). These technologies provide a means for sharing large amounts of information among supply chain partners in a fast and economical manner, thereby addressing needs concerning coordination costs (e.g., Srinvasan et al., 1994; Mukhopadhyay et al., 1995; Choudhury et al., 1998). Consequently, this factor speeds and simplifies transactions, and thus is one aspect of transactional e-business technologies.

The second factor, labeled "price determination", included the four methods of establishing pricing with suppliers through electronic means: online bidding / tendering, online reverse auction / e-auction, industry-sponsored e-marketplaces and public e-marketplaces $(\alpha=$ 0.74). The determination of best price and other delivery terms is a critical step in the purchasing process, occurring in advance of placing an order (Monczka et al., 2002), and the potential benefits of price determination technologies include addressing issues related to transactional risk, such as small numbers bargaining (Clemons et al., 1993) and an improved ability to quickly confirm supply arrangements related to price, volume and quality (Grover and Malhotra, 2003). Hence, this factor focuses on transaction risk, i.e., opportunity cost, and as a result should also be viewed as a second factor of transactional e-business technologies.

The third factor, termed "private exchange", consisted of the items related to extranets 
and exchanges $(\alpha=0.70)$. These exchanges and extranets can be established for customers, suppliers or both. The information shared on such systems is collaborative to the individual needs of the firms in the supply chain, and may include demand management data, new product development information and employee training (Kaufman et al., 2000; CAPS Research and McKinsey \& Company, 2002). While some organizations have opted to establish private exchanges or extranets, the survey data suggests that number is quite small. This factor was included as relational e-business technologies because of the collaborative nature of the items.

\subsection{Team Usage Construct}

Building on prior research, six types of purchasing teams have been identified and generally accepted in the purchasing literature; four are internally oriented and two directly involve customers (Trent and Monczka, 1994; Murphy and Heberling, 1996; Trent, 1998; Johnson et al., 2002). Similar to e-business technology usage, respondents were asked to rate the extent to which their organization made use of each type of team on a five-point Likert scale. Table 5 summarizes the sample mean scores for the relative usage of the six types of purchasing teams.

For this sample, confirmatory factor analysis was used to assess the pattern of internal and customer team usage against the scales identified in prior research (Johnson et al., 2002). The earlier factor pattern, which employed a different sample, was replicated, and all parameter loadings on the two team factors were significant $(\mathrm{p}<.01)$ and overall model fit was good, although the chi square statistic was significant $\left(\mathrm{AGFI}=0.93 ; \mathrm{CMIN} / \mathrm{DF}=2.80 ; \chi^{2}=22.3\right)$.

\subsection{Structure and Sector}

Industry context (manufacturing, processing, resource high capital-intensive services and low capital-intensive services sectors) and firm characteristics (organizational structure and firm size) have been included in this research as control variables. Purchasing's organizational structure 
was based on a self-reported measure with five categories of centralized, centralized hybrid, hybrid, decentralized hybrid and decentralized. To improve the consistency of responses, each organizational structure was defined for the respondents (Appendix A).

Industry classification was performed at two levels. First, firms were grouped in five industry groups, based on their two-digit SIC code classification: discrete goods manufacturing, process manufacturing, resource and construction, high capital-intensive-service or low capitalintensive service firms. While greater precision might be possible, this classification controlled for broad industry-based differences in the adoption of e-business technologies. Discrete goods included: furniture; leather; fabricated metal; machinery; electronic equipment; transportation equipment; instruments; and miscellaneous manufacturing sectors. Process industries included: primary metal; lumber; rubber; and stone. Resource and construction industries included: metal; coal; oil and gas; and heavy construction industries.

Previous research has classified service firms on a variety of dimensions (e.g., Thomas, 1978; Kotler, 1983; Schmenner, 1986; Haywood-Farmer, 1988). However, capital intensity provides a direct carryover to e-business technologies, as many e-business technologies require significant capital investment in infrastructure. For the respondents, a total of 103 service firms were identified based on two-digit SIC codes (i.e., SIC > 39); 15 two-digit SIC codes in the service sector had at least one respondent firm. Based on financial data for all publicly traded service firms Compustat (2003) (1,858 service firms across 15 two-digit SIC codes), the ratio of net sales to property, plant and equipment was calculated for each firm. Next, the industry-level average was calculated, and then sorted, low to high. Using this average ratio, a break-point was established at 3.0 for high vs. low capital-intensive service firms. High capital-intensive industries included: railroad transportation; air transportation; communications; electricity and 
gas; eating and drinking; and automotive repair. Low capital-intensive industries included: motor freight transportation; transportation services; credit institutions; insurance carriers; insurance agents and brokers; hotel; business services; motion pictures; and engineering, accounting and research. In summary, the final sample included 77 discrete goods manufacturing firms, 94 process manufacturing firms, 53 high capital-intensive service firms, 50 low capital-intensive services firms and 10 resource-based firms. Either the discrete goods manufacturing industry or service industries formed the reference group for the regression analysis.

\subsection{Firm Performance and E-Business Technology Usage}

To begin, an appropriate benchmark year for growing use of the Internet for e-business technology was needed. Government survey data reported the following trend for the percentage of enterprises that used the Internet to buy goods and services: $13.8 \%$ (1999), 18.2\% (2000), 54.5\% (2001), 64.2\% (2002), and 68.2\% (2003) (Statistics Canada, 2003). Thus, the tripling of use between 2000 and 2001 indicated that 2000 was a reasonable choice as a base year, at which time firms had relatively little use of e-business technologies.

Methods for assessing changes in financial performance continue to evolve in the research literature. Of particular concern is the specification of test statistics, as bias for good (or bad) performance can be overlooked or overemphasized. Underlying much of this concern is the natural tendency for firms to regress to the mean over time. As a result, it is important to assess a particular firm (i.e., observation) against a portfolio of firms with similar performance (i.e., strong or weak), and then compute how the firm of interest deviated positively or negatively from its peers. Thus, the best estimate of a firm's future financial performance is based on the change in performance of a portfolio of similar peer firms. Focusing on a peer control group eliminates the need for a long list of control variables, such as size and debt-to-equity ratio. 
Based on extensive testing, Barber and Lyon (1996) identified a multi-step process for measuring and testing changes in financial performance. This approach has also been adopted in recent research in operations management in quality (Corbett, et al., 2005) and supply chain management (Hendricks and Singhal, 2004). First, an estimate is made of the expected change in financial performance measure relative to a portfolio of peer firms:

$$
\mathrm{E}\left(\mathrm{P}_{1}\right)=\mathrm{P}_{0}+\left(\mathrm{I}_{1}-\mathrm{I}_{0}\right)
$$

where:

$\mathrm{P}_{\mathrm{i}}=$ performance for the adopting firm (i.e., observation) at time $i$

$\mathrm{I}_{\mathrm{i}}=$ median performance of a portfolio of peer firms at time $i$

$\mathrm{E}\left(\mathrm{P}_{\mathrm{i}}\right)=$ expected performance of the adopting firm at time $i$

$\mathrm{i}=0$, for the base year or initial year of the study (i.e., the year in which the portfolio of peer firms is identified, 2000)

$=1$ for the final year in the period being studied (i.e., 2003)

Based on the difference between the observed, actual performance, $\mathrm{P}_{1}$, and the expected performance, $\mathrm{E}\left(\mathrm{P}_{1}\right)$, the abnormal performance (i.e., positive or negative deviation) is computed:

$$
\mathrm{Abn}=\mathrm{P}_{1}-\mathrm{E}\left(\mathrm{P}_{1}\right)
$$

where:

$A b n=$ abnormal performance for the adopting firm over the interval (i.e. 2000 to 2003)

Barber and Lyon (1996) also provide specific criteria to ensure that a suitable portfolio of peer firms can be constructed for all observations. First, all firms with the same two-digit SIC code and financial performance within $90 \%$ to $110 \%$ of the adopting firm are identified and used to construct the portfolio of peer firms. If a portfolio can not be built with these two criteria, the SIC criterion is relaxed to include all firms with the same one-digit SIC code (financial performance must still be within $90 \%$ to $110 \%$ of the adopting firm). Finally, if a portfolio still cannot be constructed, the SIC criterion is further relaxed (i.e., zero-digit) while retaining the financial performance criterion. 
Return on assets (ROA) is a commonly used financial performance measure. Of the 284 respondent firms, portfolios of similar peer firms based on industry (two-digit SIC code) and financial performance (within $90 \%$ to $110 \%$ ) were constructed for 190 firms. An additional five firms were added at the one-digit level, and finally one additional firm was added at the zerodigit SIC level. Collectively, these steps yielded estimates of the abnormal performance for a total of 196 firms. Similar steps were taken for return on sales (ROS), which yielded a total of 195 firms. (The two financial measures are formally defined in the Appendix.)

\subsection{Case Studies}

Follow-up interviews with four respondent companies were completed to explore the relationship between purchasing teams and e-business technologies. Random selection of sites in case-based research is neither required nor recommended (Eisenhardt 1989). Consequently, the researchers used theoretical sampling, which involves the selection of cases for theoretical, not statistical, reasons (Glaser and Strauss 1967; Eisenhardt 1989; McCutcheon and Meredith 1993). Each site was purposely selected based on the on the relative use of e-business technologies (relational and transactional), purchasing team usage (internal and customer), and performance outcomes to permit comparisons among the sites.

At each site interviews were conducted with the CPO, a member of senior manager (e.g., CFO or vice president operations) and two or three senior members of the purchasing organization. The use of an interview protocol is recommended for case-based research. A protocol containing approximately 25 questions was developed, although the interviews were semi-structured to allow opportunities for the interviewees to volunteer information and for the interviewers to pursue interesting and relevant lines of questioning. Multiple sources of evidence were used, including relevant documents and other related information collected. In addition, 
each organization was a public company, which meant that annual reports and other additional information could be collected from company Web sites. Finally, Yin (1994) recommends having key informants check case reports as a method of improving validity. Consequently, the cases were sent to each site in order to provide an opportunity for review by appropriate individuals.

\section{Empirical Results}

\subsection{E-Business Technology Usage}

Initially, the average level of adoption for the three forms of e-business technology was compared. As evident from Table 6, dyadic coordination was the most widely utilized (mean $=$ 2.91 ), followed by price determination $($ mean $=1.97)$, and finally private exchange $($ mean $=$ 1.65). All differences are statistically significant at $\mathrm{p}<0.01$.

A linear regression model was proposed to assess the linkage between team usage, industry context, and purchasing organization structure for the adoption of e-business technologies. However, it quickly became apparent that the heavy clustering at the lower bound for two of the three dependent factors (i.e., variables), namely price determination and private exchange, might create estimation problems. Standard regression techniques (OLS) can provide inconsistent parameter estimates when applied to data that include a large portion of observations equal to the lower bound for the dependent variable (Greene, 2003). Here, the heavy clustering of observations at 1 (the lower bound of the four-item scales) was problematic for price determination and private exchange, with $19 \%$ and $37 \%$ of observations at the lower bound of one, respectively. By way of contrast, linear regression presented no unusual challenges for the dyadic scale, as only $3 \%$ of observations were at the lower bound.

In such a situation, a censored regression model is employed, also referred to as a Tobit 
model (Greene, 1993). While more commonly used in econometrics (the classic case is household purchases of durable goods), this approach also has been reported in the management literature for assessing technology transfer (Feldman et al., 2002) and joint ventures (Reuer and Leiblein, 2000). The Tobit model can be expressed as:

$$
Y_{i}^{*}=\boldsymbol{X}_{i}^{\prime} \boldsymbol{\beta}+\varepsilon_{i},
$$

where

$$
\begin{gathered}
Y_{i}=1 \text { if } Y_{i}^{*} \leq 1 \\
Y_{i}=Y_{i}^{*} \text { if } Y_{i}^{*}>1 .
\end{gathered}
$$

$\mathrm{Y}^{*}$ becomes a latent variable that is observed when the value of the dependent variable is greater than $1 . \mathrm{X}$ is a vector of explanatory variables, $\beta$ is a coefficient vector, and $\varepsilon$ is an error term assumed to be normally distributed. The Tobit model is estimated using maximum likelihood estimation, and a Wald-test $\left(\chi^{2}\right.$ statistic) replaces the t-test from OLS to test the statistical significance of individual parameter estimates.

E-business technology use was assessed for dyadic coordination, price determination and private exchange (Table 7). (It should be noted that the final parameter estimates using a Tobit model were very similar to OLS estimates, particularly for dyadic coordination with few censored observations.)

The results for e-business technology usage offer several interesting findings. First, the results indicate a significant relationship between team usage and e-business technologies use ( $\mathrm{H} 1$ and $\mathrm{H} 2$ ). All three forms of e-business technology usage — dyadic, price determination and private exchange-increased significantly as internal team usage increased $(\mathrm{p}<0.01)$. In contrast, while customer teams also significantly influenced the use of price determination $(\mathrm{p}<$ $0.01)$ and private exchange $(\mathrm{p}<0.05)$, no relationship was detected with dyadic coordination ( $\mathrm{p}$ 
$>0.10)$. Consequently, these results suggest a much broader relationship between team usage and e-business technologies than proposed in Hypotheses 1 and 2. The only exception is the influence of customer teams on dyadic coordination. This form of e-business technology is related to upstream supply chain activities, which would not typically require the involvement of customers.

\subsection{E-Business Technology and Firm Performance}

Standard OLS regression was used to model the relationship between financial performance and the use of e-business technologies. For consistency with the earlier analysis, team usage, industry context, and other firm characteristics also were included.

Casewise diagnostics indicated that five observations had standardized residuals greater than three standard deviations (three observations for ROS and two for ROA). Further investigation of those five using public media sources indicated that significant merger and acquisition activity during the three-year period of study. For example, one firm merged with another similar-sized firm, and then went on to acquire another four companies. Two other firms sold business units and acquired others during the study period. The last two firms also made significant acquisitions during this time. As a result, these five firms were removed from subsequent analysis, leaving a total of 191 firms in the sample.

The results reported in Table 8 show that financial performance was significantly related to the use of dyadic coordination, one factor of transactional e-business technologies, for both ROA and ROS relative to a portfolio of peer firms, giving support to H3 $(\mathrm{p}<0.01)$. In contrast, no evidence was found to support a positive relationship between financial performance and either price determination (the other transaction technology factor) or private exchange, i.e., relational e-business technologies. The consistency of the two regression models offers some 
support for the general robustness of the results.

\subsection{Structure, Size and Sector}

Purchasing's organizational structure was significantly related to price determination and dyadic coordination $(\mathrm{p}<0.05)$, but not private exchange use $(\mathrm{p}>0.10)$. For the first two models, as the organization became increasingly centralized, e-business technology usage increased. Firm size was also significantly related to price determination and dyadic coordination $(\mathrm{p}<0.01)$, where usage increased as firm size increased. However, organizational structure and firm size did not influence the use of private exchange technologies.

The use of price determination e-business technologies was greater for manufacturing firms compared to service firms. The most significant differences were observed between lowcapital intensive services and resource-based industries for all three forms of technology $(\mathrm{p}<$ 0.01, 0.05, and 0.10, respectively). Low-capital intensive services favored dyadic coordination, whereas resource-based firms favored price determination and private exchanges. The other three industries occupied the spectrum between these two.

\subsection{Case Studies}

All sites for the case studies were large North American companies with annual sales ranging from $\$ 5$ billion to $\$ 30$ billion. Site A was from the machinery manufacturing sector, site B from the electrical equipment manufacturing sector, site $\mathrm{C}$ from the food manufacturing sector and site D from the insurance sector. Table 9 summarizes key findings from the case studies, including company demographics, how the sites used e-business technologies and purchasing teams, the motivation for e-business technology and purchasing team use and investments in e-business technology.

Findings indicated differences among sites concerning e-business technology and 
purchasing team use. Site A used dyadic and price determination technologies extensively to support cross functional and supplier teams for cost reduction initiatives and in new product development. E-business technologies were also leveraged to facilitate information sharing between Site A and its key suppliers to reduce transaction costs and improve communication capabilities. Site A had supported its e-business initiative with a large staff for more than a decade.

In contrast, Site B had only recently started its e-business program - a team had been developed within the last year to implement a new ERP system. Strategic sourcing teams had pushed for investments in e-business technologies to support a corporate database that could be used to identify opportunities for cost reductions. The company also saw opportunities to reduce transaction costs through the introduction of new e-business systems in areas such as order processing.

Site $\mathrm{C}$ had made substantial investments in e-business technologies, starting in the early 1990s when then purchasing department was a major initiator in its investment in an SAP system. Here too, cost reduction opportunities were major drivers for its investments in ebusiness technologies. Sourcing teams worked on initiatives examining opportunities for waste reduction from raw material suppliers, operations and distribution. Site C's global supply extranet facilitated exchange of information among supply chain partners on a real-time basis, organized in four areas: content, commerce, collaboration and community. The extranet provided a number of supplier self-service areas as a means of integrating suppliers into business processes and information flow. The supplier self-service initiative required suppliers to take responsibility for accessing and maintaining certain data and information, in areas such as supplier managed inventories, specifications and payments. Similarly, important customers, such 
as Wal-Mart and their "Retail Link", were expecting the company to take more responsibility for fulfillment activities, such as managing deliveries and inventories.

Site D was a financial services firm with decentralized and globally dispersed operations. The company used e-business technologies to simplify its purchasing processes and reduce transaction costs. E-business technologies were process driven to provide users with easy access and help control costs and budgets. Their strategy was to move transaction based processes online using supplier portals. Major outcomes included easy access to users, process/transaction cost reduction, standardized systems and processes, and centralized data management. The CPO relied on the contracting/sourcing process and did not believe that price determination technologies, such as reverse auctions, fit with the sourcing needs of the organization. User engagement was identified by the CPO as the "key enabler for success" of purchasing. Teaming was mainly internal and carried out up-front in the sourcing process-sourcing managers facilitated and led cross-functional teams that included key user groups. Suppliers were not engaged until after the source selection stage.

\section{Discussion}

\subsection{E-Business Technology Use}

The empirical results point to several important findings that contribute to a better understanding of management's use of e-business technologies in supply chains. Based on reported patterns of use, findings indicate that a two-dimensional taxonomy for e-business technology is appropriate, including transactional and relational dimensions. However, transactional technologies can be further subdivided into two factors: dyadic cooperation and price determination. The first factor emphasizes coordination costs, while the second focuses on transaction risk. Finally, relational technologies were represented by private exchanges that seek to enhance the overall level of 
strategic integration among supply chain partners.

An important finding of this research is that the adoption of some forms of e-business technology use can lead to improved financial performance. While there is considerable debate in the literature concerning the relationship between information technology use and performance, our findings identify where short term opportunities reside within the context of supply chain management. Specifically, e-business technologies that are designed to reduce coordination costs lead to measurable improved performance; in contrast, no evidence was found that technologies oriented toward transaction risk and relational aspects improved performance. This finding suggests that firms are leading their e-business technology implementation with tools that help to reduce coordination costs, such as online purchase order systems, supplier catalogues, EDI and electronic linkage with suppliers, consistent with TCE (Williamson, 1991). Dyadic coordination may also represent an area of "low hanging fruit" for many firms that are beginning to build capabilities in e-business.

In addition, significant differences were found between the levels of adoption of the three e-business technology factors, with dyadic coordination being the most widely adopted. Despite the excitement about supply chain opportunities afforded by e-business technologies (e.g., Smeltzer and Carr, 2002; Talluri and Ragatz, 2004), the level of adoption of price determination and private exchange technologies was relatively low. The high use of dyadic coordination technologies, relative to price determination and private exchanges, implies that firms have recognized the opportunities afforded by these technologies, and have focused implementation in areas that provide short-term financial benefits. Consequently, firms may be taking a more cautious approach to implementing price determination and private exchange technologies.

The case studies helped to shed light on factors influencing the adoption of e-business 
technologies. First, each site saw adoption of e-business technologies as tools to reduce transaction costs and improve the speed and accuracy of business processes. A major benefit identified by the respondents was the opportunity to shift resources (e.g., staff) from transactional processing to sourcing and other value-adding activities. Consequently, e-business technology adoption started with automation of business processes, such as on-line purchasing order systems. Interestingly the sites that operated private exchanges also looked for significant savings in transaction costs-with relational benefits pursued in the advanced stages of ebusiness technology adoption. For example, site A formed its supply management e-business group in 2000 and by July 2006 it had been enlarged 30 people. Its "supplynet" portal could be accessed by both suppliers and company employees. Supplier tools ranged from invoicing, project tracking, on-line PO submissions, supplier evaluation system and a variety of forms (e.g., supplier diversity forms). The internal portal provided a range of information on commodities, such as preferred suppliers, commodity owners and volumes. The current focus was expanding the functionality of the supplynet portal to areas such as new product development and cost reduction programs.

Second, the case studies also identified linkages between strategic sourcing processes and e-business technology use. At each site the strategic sourcing processes drove the types of ebusiness technologies adopted. For example, site D was a decentralized organization and its operations were global and geographically dispersed. The CPO indicated that he relied on the contracting/sourcing process and did not believe that price determination technologies, such as reverse auctions, fit with the sourcing needs of the organization. Instead, their strategy was to spend time up-front identifying needs and negotiating with suppliers. E-business technologies were regarded as a means to provide access to employees and control costs. The CPO indicated 
that his strategy was to: "Use e-business technologies to simplify the purchasing process and reduce transaction costs by moving transaction based processes on-line." Examples cited were using supplier portals for ordering and invoicing related to purchases such as information technology (e.g., computers), photocopiers, travel and office supplies.

Third, e-business technologies were also an enabler for supply chain integration. At site C, the technology solutions adopted included a "supply network" intranet and a "global supply extranet" for suppliers (relational technologies). The global supply extranet facilitated exchange of information among supply chain partners on a real-time basis, organized in four areas: content, commerce, collaboration and community. It provided a number of supplier self-service areas as a means of integrating suppliers into business processes and information flow. The supplier self-service initiative required suppliers to take responsibility for accessing and maintaining certain data and information, in areas such as supplier managed inventories, specifications and payments. Similarly, important customers, such as Wal-Mart and their "Retail Link", were expecting the company to take more responsibility for fulfillment activities, such as managing deliveries and inventories.

\subsection{E-Business Technology and Purchasing Teams}

The findings reported here provide evidence of the critical role that at least one strategic resource, i.e., purchasing teams, plays in the development and implementation of e-business technologies. RBV specifies that firms seek to acquire and control bundles of resources that, when combined, become sources of competitive advantage. The literature suggests that superior deployment capabilities can provide a sustainable competitive advantage (Christensen and Overdorf, 2000; Day, 1994), and in the context of this research, firms seeking to deploy ebusiness technologies in their supply chain can enhance this through leveraging teams. Note that 
this implication is important, regardless of the teams being formed to respond to the perceived need to adopt e-business technologies, or the team itself initiated their adoption. Consequently, our findings suggest that competitive advantage flows from the capabilities created by teams (internal and customer teams) for e-business technologies.

It was interesting to observe that customer teams did not influence the most widely used e-business technology category, namely dyadic coordination. In retrospect, this finding fits with typical applications of dyadic coordination, where cross-functional coordination and planning, rather than customer involvement, is needed to replace manual, paper-based systems with electronic systems. Internal teams can play a central role in such initiatives by coordinating projects that reengineer business processes and select suppliers.

The case studies revealed the influence of purchasing teams on e-business technology use, and specifically, the relationship between purchasing teams and use of price determination technologies. For example, site B used "commodity review teams" consisting of six to ten individuals, including people from purchasing and materials management, sales and operations. The review cycle typically lasted six months and involved a total spend of approximately $\$ 1.1$ billion. Although there were opportunities to use reverse auctions for the purchase of standard "commodity like" items, such as printed circuit boards, stampings, cables and fasteners, management preferred to use rely on its strategic sourcing process. Similarly, the CPO at site D relied on the contracting/sourcing process and did not believe that price determination technologies, such as reverse auctions, fit with the sourcing needs of the organization. Their strategy is to spend time up-front identifying needs and negotiating with suppliers.

The use of electronic databases was also identified by the case study respondents as critical for strategic sourcing. Site B had created a global process transformation team to 
implement a new ERP system that would create a common centralized global database linking plants and head office functions (e.g., supply). The objectives were to reduce transaction costs by automating business processes, improve fulfillment speed, support early supply and supplier involvement in NPD and support a new low cost country sourcing initiative by providing information on the company's global operations.

In addition, the case studies highlighted the importance of cross-functional teams and teams with suppliers and the difficulties in customer engagement in purchasing teams. For example, at site A, teaming was characterized by a heavy emphasis on cross-functional teams and early supplier involvement. The company's strategy was to form strategic relationships with suppliers and involve them early in the purchasing process - at the product design stage. This has been a major change in approach during the past four to five years. However, customer involvement on purchasing teams was problematic because of the $\mathrm{B} 2 \mathrm{C}$ nature of the business.

\subsection{Implications for Managers}

Findings from this research have several important managerial implications. First, they provide benchmarks for managers with respect to implementation progress for e-business technologies. Dyadic coordination technologies, one factor of transactional e-business technology, represents not only the most popular, but are also the only e-business technology for which evidence was found of improved financial performance. Previous research has demonstrated that chief purchasing officers are under considerable pressures to reduce costs while shrinking their functional headcounts (Johnson and Leenders 2004). This research illustrates that in many large North American companies, the approach taken is to automate basic supply chain processes (e.g., dyadic coordination) so that human resources can be deployed in more productive areas, likely in areas such as strategic sourcing and supplier development. 
Our case studies illustrate the importance of integrating e-business technology use with the organization's sourcing strategy. In particular, consideration of price determination and private exchange e-business technologies must be balanced against other methods, such as negotiation and competitive bidding. The case studies illustrated that organizations emphasized their sourcing strategy and looked for opportunities to use e-business technologies in areas that enhanced the sourcing process.

One further implication for managers is identifying which supply chain processes should be targeted initially when adopting e-business technologies. Our survey and case studies found that firms are focusing on automating basic supply chain processes to reduce transaction costs before using e-business technologies for supply chain integration and collaboration. Consequently, executives considering "taking the next step" and investing in e-business technologies should favor of solidifying deployment in dyadic technologies. In addition, our case studies found that even when implementing relational e-business technologies firms started with basic processes such as invoicing and fulfillment.

As we found at site $\mathrm{B}$, the choice of appropriate e-business technologies needs to be supported with effective deployment and use. Thus, senior managers should recognize the need to integrate e-business technologies use and deployment with internal and external purchasing teams, or at least deploy teams to smooth their implementation. Cross-functional involvement supported by supplier and customer participation, increases levels of e-business technology use in the supply chain. This research provides some support for the position that it is not the technology alone that provides competitive advantage, but rather the ability of the information systems function to work effectively with others in the organization, including the supply chain function, and with critical external supply chain partners (e.g., customers and suppliers). 
Ultimately the objective must be to develop the skill set to implement these technologies successfully, so that this capability represents a competitive advantage.

\subsection{Limitations}

Several limitations of this study are important to note. First, while the sample size was quite large, statistical power may still be insufficient to detect smaller effects related to those hypotheses for which no support was found. As such, the primary contribution here is the identification of firm-level factors that were related to e-business use, rather than establishing those that were not. Second, the potential for respondent bias is always a concern. However, validation was found for several scales, such as those for purchasing team usage, that were drawn directly from earlier studies, which employed a different dataset (e.g., Johnson et al., 2002). Third, because the sampling frame and financial analysis only assessed firms for a threeyear time frame, there may be concerns that some of the e-business technologies take longer to exhibit positive returns, particularly given the low usage levels reported for technologies like private exchanges. Moreover, early adopters may not have implemented these technologies in the most effective manner, something that is likely to correct itself over time as collective experience grows.

\section{Conclusions}

This research had two primary objectives. The first objective was to gain a better understanding of potential drivers of e-business technology use, including firm-level strategic resources such as purchasing teams. The second objective was to explore the relationship between e-business technology use and firm performance. Drawing from three literatures, transaction cost economics, RBV and the relational view, a two-dimensional framework was constructed for ebusiness technology: transactional and relational technologies. Further empirical analysis 
dissected the transactional e-business technology dimension into two factors: dyadic coordination and price determination. In contrast, private exchange was identified as a relational technology factor.

Overall, with the exception of dyadic coordination, the use of e-business technologies was low. However, as the use of strategic resources expanded, in particular internal teams and customer teams, the use of e-business technology expanded. Purchasing structure and firm size also were found to influence the adoption of dyadic coordination and price determination technologies, but not private exchanges. Whether centralized coordination of e-business activities is essential for effective use represents an opportunity for future research.

While no evidence was found that the use of the price determination and private exchanges technology enhanced financial performance, clear evidence was found to indicate that firms benefited from the use of dyadic coordination technologies. This finding might help to explain the earlier finding of the greater relative use of dyadic coordination technologies, as managers have been investing more heavily in forms of e-business technology that offered early gains from relatively small early investments.

Findings from this research suggest several opportunities for future research. Why is implementation of price determination and private exchange technologies lagging behind dyadic coordination? Our case study research suggests that sourcing strategies have an important influence on the adoption of these technologies. Further research may provide a clearer understanding of the major hurdles for adoption, as well as how particular forms, such as dyadic coordination, price determination and private exchanges, might collectively build competitiveness.

Our findings also suggest that e-business technology use increases as organizational 
centralization increases. Consequently, as e-business technologies increase in use over coming years, it may become increasingly difficult for firms to completely decentralize their supply organizations without sacrificing performance benefits associated with e-business technology use and adoption. Future research can explore the influence of e-business technologies on supply organizational structures and responsibilities.

\section{References}

Alderfer, C.P., 1977. Group and intergroup relations. in J.R. Hackman and J.L. Suttle (Eds.), Improving Life at Work, Goodyear, Palisades, CA, 227-296.

Armstrong, J.C.; Overton T.S., 1977. Estimating nonresponse bias in mail surveys." Journal of Marketing Research, 14 (3), 396-402.

Barber, B.M.; Lyon, J.D., 1996. Detecting abnormal operating performance: the empirical Power and specification of test statistics. Journal of Finance Economics 41, 359-399.

Barney, J. 1991. Firm resources and sustained competitive advantage.” Journal of Management 17 (1), 99-120.

Barringer, B.R.; Harrison, J.S., 2000. Walking a tightrope: creating value through interorganizational relationships. Journal of Management 26 (3), 367-403.

Barua, A.; Konana, P.; Whinston, A.B.; Yin, F., 2004. An empirical investigation of newenabled business value. MIS Quarterly 28 (4), 585-620.

Beall, S. et al., 2003. The role of reverse auctions in strategic sourcing, research paper, CAPS Research, Tempe, Arizona.

Bechtel, C.; Jayanth, J., 1997. Supply chain management: a strategic perspective. The International Journal of Logistics Management 8(1), 15-34.

Bharadwaj, A.S., 2000. A resource-based perspective on information technology capability and firm performance: an empirical investigation. MIS Quarterly 24 (1) 169-196.

Black, J.A.; Boal, K.B., 1994. Strategic resources: Traits configuration and paths to sustainable competitive advantage. Strategic Management Journal 15, 131-148.

Boone, T.; Ganeshan, R., 2004. Call for papers: special issue on the impact of ebusiness technologies on supply chain operations. Journal of Operations Management, 22, 197198.

Boyer, K.K.; Olson, J.R., 2002. Drivers of Internet purchasing success. Production and Operations Management 11 (4), 480-498.

CAPS Research and McKinsey \& Company, 2002. E-commerce exchanges. CAPS Research, Tempe, AZ.

Carter J.R.; Narasimhan, R., 1996. Purchasing and supply management: Future directions and trends. International Journal of Purchasing and Materials Management 32 (4), 2-12.

Choudhury, V.; Hartzel, K.S.; Konsynski, B.R., 1998. Uses and consequences of electronic markets: an empirical investigation in the aircraft parts industry. MIS Quarterly 22 (4), 471-507.

Christensen, C.M.; Overdorf, M., 2000. Meeting the challenge of disruptive change. Harvard Business Review 78 (2), 67-75. 
Clemons, E.K.; Reddi, S.P.; Row, M.C., 1993. The impact of information technology on the organization of economic activity: the 'move to the middle' hypothesis. Journal of Management Information Systems 10 (2), 9-35.

Coff, R.W., 1999. When competitive advantage doesn't lead to performance: the resource-based view and stakeholder bargaining power," Organization Science, 10 (2), 119-133.

Compustat, 2003. "Compustat Annual Industrial File." accessed using Wharton Research Data Services, http://wrds.wharton.upenn.edu, The Wharton School of the University of Pennsylvania.

Corbett, C.J.; Montes-Sancho, M.J.; Kirsch, D.A., 2005. The financial impact of ISO 9000 certification in the US: an empirical analysis." Management Science, 51 (7), 1046-1059.

Day, G., 1994. The capabilities of market-driven organizations. Journal of Marketing 58 (4), 3752.

Deeter-Schmelz, D.; Bizzari, A.; Graham, R.; Howdyshell, C., 2001. Business-to-business online purchasing: suppliers' impact on buyers' adoption and usage intent." The Journal of Supply Chain Management, 37 (1), 4-10.

Denison, D.R.; Hart, S.L.; Kahn, J.A, 1996. "From Chimneys to cross-functional teams: developing and validating a diagnostics model. Academy of Management Journal, 39 (4), 1005-1023.

Dierickx, I.; Cool, K., 1989. Asset stock accumulation and sustainability of competitive advantage." Management Science 35 (12), 1504-1511.

Dillman, D.A., 2000. Mail and Internet surveys: the tailored design method, second edition, John Wiley and Sons, New York, NY.

Dyer, J.H., 1996. How Chrysler created an American keiretsu. Harvard Business Review 74 (4), 42-56.

Dyer, J.H.; Singh, H., 1998. The relational view: Cooperative strategy and sources of interorganizational competitive advantage. Academy of Management Review 23 (4), 660-679.

Ellram, L.M.; Pearson, J.N., 1993. The role of the purchasing function: toward team participation. International Journal of Purchasing and Materials Management 29 (3), 3-9.

Eisenhardt, K.M., 1989. building theories from case study research. Academy of Management Review, 14 (4), 532-550.

Essig, M.; Arnold, U., 2001. Electronic procurement in supply chain management: an information economics-based analysis of electronic markets. The Journal of Supply Chain Management 37 (4) 43-49.

Feldman, M.; Feller, I.; Bercovitz, J.; Burton, R., 2002. Equity and the technology transfer strategies of American research universities. Management Science 48 (1), 105-121.

Frohlich, M.T., 2002. e-Integration in the supply chain: barriers and performance. Decision Sciences 33 (4), 537-556.

Giunipero, L.; Vogt, J., 1997. Empowering the purchasing function: moving to team decisions. International Journal of Purchasing and Materials Management, 8-15.

Glaser, B.G.; Strauss, A.L., 1967. The discovery of grounded theory, Chicago, Aldine.

Greene, W.H., 2003. "Econometric Analysis." fifth edition, Prentice Hall, Upper Saddle River, NJ.

Grover, V.; Malhotra, M.K., 2003. Transaction cost framework in operations and supply chain management research: theory and measurement. Journal of Operations Management 21 (4), 457-473. 
Hackman, J.R., 1990. Work teams in organizations: an oriented framework.” in J. Hackman (Ed.), Groups that work and those that don't, Jossey-Bass, San Francisco, CA.

Hair, J.F. Jr.; Anderson, R.E.; Tatham, R.L.; Black, W.C., 1995. Multivariate data analysis with readings. Fourth Edition, Prentice Hall, Upper Saddle River, NJ.

Haywood-Farmer, J., 1988. A conceptual model of service quality. International Journal of Operations and Production Management, 8 (6), 19-29.

Hendricks, K.B.; Singhal, V.R., 2004. An empirical analysis of the effect of supply chain disruption on operating performance. Working Paper, Georgia Tech University.

Hult, G.T.M., Ketchen, Jr., D.J., Nichols, Jr., E.L., 2003. Organizational learning as a strategic resource in supply management. Journal of Operations Management, 21 (5), 541-556.

Jap, S.D., 2003. An exploratory study of the introduction of online reverse auctions. Journal of Marketing 67, 96-107.

Johnson, P.F., 2003. Supply organizational structures, Working Paper, CAPS Research.

Johnson, P.F.; Klassen, R.D.; Leenders, M.R.; Fearon, H.E., 2002, Determinants of purchasing team usage in the supply chain. Journal of Operations Management, 20 (1), 77-89.

Johnson, P.F.; Leenders, M.R., 2004. Supply's organizational roles and responsibilities. Tempe, Arizona: CAPS Research.

Kaufman, A.; Wood, C.H.; Theyel, G., 2000. Collaboration and technology linkages: a strategic supplier typology. Strategic Management Journal, 21 (6), 649-663.

Katok, E.; Roth, A.E., 2004. Auctions of homogeneous goods with increasing returns: experimental comparison of alternative 'Dutch' auctions. Management Science 50 (8), 1044-1063.

Kotler, P., 1983. Principles of Marketing. Prentice-Hall, Englewood Cliffs, NJ.

Lewis, M.A., 2003. Analysing organisational competence: implications for the management of operations. International Journal of Operations \& Production Management, 23 (7/8), 731 756.

McCutcheon, D.M.; J.R. Meredith, 1993. Conducting case study research in operations management. Journal of Operations Management, 11 (3), 239-256.

Monczka, R.M.; Trent R.J.; Handfield, R.B., 2002. Purchasing and Supply Management. second edition, South-Western, Mason, $\mathrm{OH}$.

Mukhopadhyay, T.; Kekre, S.; Kalathur, 1995. Business value of information technology: a study of electronic data interchange. MIS Quarterly 19 (2), 137-156.

Murphy, D.J.; Heberling, M.E., 1996. A framework for purchasing and integrated product teams. International Journal of Purchasing and Materials Management, 32 (3) 11-19.

Neef, D., 2001. e-Procurement: from strategy to implementation. Prentice Hall, Upper Saddle River, NJ.

Nunnally, J.C.; Berstein, I.H., 1994. Psychometric theory. third edition, McGraw Hill, New York.

Philips, J., 1981. "Assessing measurement error in key informant reports: a methodological note on organizational analysis in marketing.” Journal of Marketing Research, vol. 18, no. 4, pp. 395-415.

Powell, T.C.; Dent-Micallef, A., 1997. Information technology as competitive advantage: the role of human, business, and technology resources. Strategic Management Journal 18 (5), 375-405.

Reuer, J.J., Leiblein, M.J., 2000. Downside risk implications of multinationality and international Joint Ventures. Academy of Management Journal, 43 (3), 203-214. 
Rindfleisch, A.; Heide, J.B., 1997. Transaction cost analysis: past, present, and future applications. Journal of Marketing 61 (4), 30-54.

Robey, D.; Ross, J.W.; Boudreau, M.C., 2002. Learning to implement enterprise systems: An exploratory study of the dialectics of change. Journal of Management Information Systems 19 (1), 17-46.

Rungtusanatham, M.; Salvador, F.; Forza, C.; Choi, T.Y., 2003. Supply chain linkages and operational performance: A resource-based-view perspective. International Journal of Operations and Production Management, 23 (9), 1084-1099.

Schmenner, R.W., 1986. How can service businesses survive and prosper? Sloan Management Review 27 (3), 21-32.

Smeltzer, L.R.; Carr, A., 2002. "Reverse Auctions in Industrial Marketing and Buying." Business Horizons, March/April, pp. 47-52.

Srinivasan, K.; Kekre, S.; Mukhopadhyay, T., 1994. Impact of electronic data interchange technology on JIT shipments. Management Science 40 (10), 1291-1304.

Statistics Canada, 2003. Electronic Commerce and Technology, tables 358-0007 to 358-0011, and 358-0014 to 358-0016. http://www.statcan.ca/Daily/English/040416/d040416a.htm. Accessed July 13, 2004.

Subramani, M., 2004. How do suppliers benefit from information technology use in supply chain relationships? MIS Quarterly 28 (1), 45-73.

Talluri, S.; Ragatz, G.L., 2004. Multi-attribute reverse auctions in B2B exchanges: a framework for design and implementation. The Journal of Supply Chain Management 40 (2), 52-60.

Thomas, D.R.E., 1978. Strategy is different in service businesses. Harvard Business Review, 56 (4) $158-165$.

Tippins, M.J.; Sohi, R.S., 2003. IT competency and firm performance: is organizational learning a missing link? Strategic Management Journal 24 (8), 745-765.

Trent, R.J., 1998. Individual and collective team effort: a vital part of sourcing team success. International Journal of Purchasing and Materials Management 34 (4), 46-54.

Trent, R.J.; Monczka, R.M., 1994. Effective cross-functional sourcing teams: critical success factors. International Journal of Purchasing and Materials Management 30 (4) 2-11.

Trent, R.J.; Monczka, R.M., 1998. Purchasing and supply management: trends and changes throughout the 1990s. International Journal of Purchasing and Materials Management, 34 (4) 2-11.

Wade, M.; Hulland, J., 2004. The resource-based view and information systems research: review, extension, and suggestions for future research. MIS Quarterly 28 (1), 107-142.

Weill, P.; Vitale, M., 2002. What IT infrastructure capabilities are needed to implement ebusiness models? MIS Quarterly Executive 1 (1), 17-34.

Williamson, O.E., 1991. The logic of economic organization. In O. E. Williamson and S.G. Winter, (Ed.), The Nature of the Firm: Origins, Evolution and Development, Oxford Press, New York, NY.

Williamson, O.E., 1975. Markets and Hierachies, The Free Press: New York, NY.

Wu, F.; Mahajan, V.; Balasubramanian, S., 2003. An analysis of e-business adoption and its impact on business performance. Journal of the Academy of Marketing Science 31 (4), 425-447.

Yin, R.K, 1994. Case study research design and methods. Thousand Oaks: Sage Publications, second edition. 
Zaheer, A.; Venkatraman, N., 1994. Determinants of electronic integration in the insurance industry: an empirical test. Management Science 40 (5), 549-567.

\section{Appendix A: Construct Measurement}

\section{Purchasing organizational structure}

How does your firm organize for purchasing/supply?

1. Centralized: In which all, or almost all of purchase dollars are committed at one central location for the entire firm.

2. Centralized Hybrid: In which more than 50 percent of purchase dollars are committed at one central location for the entire firm.

3. Hybrid: In which approximately 50 percent of purchase dollars are committed at one central location for the entire firm.

4. Decentralized Hybrid: In which less than 50 percent of the purchase dollars are committed at one central location for the entire firm.

5. Decentralized: In which all, or almost all of purchase dollars are committed on a divisional/plant basis for the entire company.

\section{Purchasing teams}

In performing the purchasing/supply function, to what extent does your firm make use of the following... $(1=$ none... $5=$ extensive $)$.

1. Purchasing councils (purchasing personnel only)

2. Supplier councils (primarily key suppliers)

3. Commodity teams (purchasing personnel only)

4. Cross-functional teams

5. Teams with external customers

6. Teams with suppliers and external customers

\section{E-business technology}

To what extent does your firm make use of the following forms of e-commerce...( $1=$ none... 5 $=$ extensive).

1. Electronic data interchange (EDI)

2. Real-time electronic linkage with suppliers

3. Electronic / online supplier catalogue

4. Electronic / online purchase order system

5. Online reverse auction / e-auction

6. Online bidding / tendering

7. Public e-marketplaces (e.g. Global Healthcare Exchange) 
8. Industry-sponsored e-marketplaces (e.g. Covisint)

9. Private B2B exchange / Extranet - operated by your company for your suppliers

10. Private B2B exchange / Extranet - operated by your supplier(s)

11. Private B2B exchange / Extranet - operated by your company for your customer(s)

12. Private B2B exchange / Extranet - operated by your customer(s)

Financial performance

All financial data was extracted from Compustat (2003).

Return on assets $=$ net income before interest, taxes and depreciation $/$ total assets

Return on sales $=$ net income before interest, taxes and depreciation $/$ gross sales 
Table 1

Research in E-Business Technologies

\begin{tabular}{|c|c|c|c|c|}
\hline Study & E-Business Variables & Performance Variables & Methodology & Major Findings \\
\hline $\begin{array}{l}\text { Mukopadhyay } \\
\text { et al. (1995) }\end{array}$ & $\begin{array}{l}\text { - Level of EDI penetration, } \\
\text { measured by the percentage of } \\
\text { material dollars procured with } \\
\text { EDI }\end{array}$ & $\begin{array}{l}\text { - Obsolete inventory costs } \\
\text { - Inventory turnover } \\
\text { - } \text { Premium freight costs }\end{array}$ & $\begin{array}{l}\text { Model of cross-sectional and } \\
\text { time-series data collected } \\
\text { from nine assembly plants at a } \\
\text { large North American } \\
\text { automotive manufacturer }\end{array}$ & $\begin{array}{l}\text { - Cost savings result from the } \\
\text { use of EDI at the company } \\
\text { studied }\end{array}$ \\
\hline $\begin{array}{l}\text { Frohlich } \\
(2002)\end{array}$ & $\begin{array}{l}\text { - Supplier and customer e- } \\
\text { integration: use of web-based } \\
\text { technologies for planning, } \\
\text { forecasting, scheduling and } \\
\text { customer relationship } \\
\text { management }\end{array}$ & $\begin{array}{l}\text { E-business performance: } \\
\text { Percentage of purchases and } \\
\text { sales conducted using the } \\
\text { Internet. } \\
\text { - Operational performance: } \\
\text { respondent perception of } \\
\text { delivery times, transaction } \\
\text { costs and inventory turnover }\end{array}$ & $\begin{array}{l}\text { - Survey of } 486 \text { U.K. } \\
\text { manufacturing companies in } \\
\text { early } 2001\end{array}$ & $\begin{array}{l}\text { - Positive link between supplier } \\
\text { and customer e-integration and } \\
\text { e-business and operational } \\
\text { performance }\end{array}$ \\
\hline $\begin{array}{l}\text { Boyer and } \\
\text { Olson }(2002)\end{array}$ & - Internet purchasing & $\begin{array}{l}\text { Respondent perceptions of } \\
\text { cost (purchasing cost and } \\
\text { training cost) and accuracy } \\
\text { (billing accuracy and } \\
\text { availability) performance }\end{array}$ & $\begin{array}{l}\text { - Survey of } 416 \text { customers, that } \\
\text { only ordered over the Internet, } \\
\text { of a major retailer of office } \\
\text { supplies in } 2000\end{array}$ & $\begin{array}{l}\text { - Internet purchasing leads to } \\
\text { performance benefits }\end{array}$ \\
\hline Wu et al. 2003 & $\begin{array}{l}\text { - Outbound communications } \\
\text { - Inbound communications } \\
\text { - Online order taking } \\
\text { - e-Procurement }\end{array}$ & $\begin{array}{l}\text { Respondent perception of } \\
\text { efficiency, sales performance, } \\
\text { customer satisfaction and } \\
\text { relationship development }\end{array}$ & $\begin{array}{l}\text { - Survey of } 144 \text { U.S. companies } \\
\text { in four technology-intensive } \\
\text { industries in spring } 2001\end{array}$ & $\begin{array}{l}\text { - Online order taking and e- } \\
\text { procurement did not influence } \\
\text { performance } \\
\text { - E-business adoption of } \\
\text { inbound and outbound } \\
\text { communications influence } \\
\text { performance }\end{array}$ \\
\hline $\begin{array}{l}\text { Barua et al. } \\
2004\end{array}$ & $\begin{array}{l}\text { - Online informational } \\
\text { capabilities: The ability to } \\
\text { exchange strategic and tactical } \\
\text { information with customers and } \\
\text { suppliers on-demand }\end{array}$ & $\begin{array}{l}\text { Financial performance: } \\
\text { revenue per employee, gross } \\
\text { profit margin, return on } \\
\text { assets, return on investment }\end{array}$ & $\begin{array}{l}\text { - Survey of } 1,076 \text { firms in } \\
\text { manufacturing, retail, } \\
\text { wholesale and distribution, } \\
\text { conducted in early } 2000\end{array}$ & $\begin{array}{l}\text { - Online information capabilities } \\
\text { on customer side leads to } \\
\text { improved financial } \\
\text { performance } \\
\text { - Online information capabilities } \\
\text { on supply side did not lead to } \\
\text { improved financial } \\
\text { performance }\end{array}$ \\
\hline
\end{tabular}


Table 2

Respondents' Sales

\begin{tabular}{lcc}
\hline \multicolumn{1}{c}{ Annual Sales (in US dollars) } & Frequency & Percentage \\
\hline under \$500 million & 22 & $7.8 \%$ \\
\$500 million to \$1 billion & 19 & $6.7 \%$ \\
\$1 billion to \$5 billion & 108 & $38.0 \%$ \\
\$5 billion to \$10 billion & 62 & $21.8 \%$ \\
over \$10 billion & 73 & $25.7 \%$ \\
Total & 284 & $100 \%$ \\
\hline
\end{tabular}

Table 3

Use of E-Business Technologies

\begin{tabular}{lcc}
\hline \multicolumn{1}{c}{ E-Business Technology Activity } & Mean $^{\dagger}$ & Std. Dev. \\
\hline Electronic / online purchase order system & 3.18 & 1.35 \\
Electronic data interchange (EDI) & 3.06 & 1.24 \\
Electronic / online supplier catalogue & 2.84 & 1.04 \\
Real-time electronic linkage with suppliers & 2.57 & 1.12 \\
Online reverse auction / e-auction & 2.49 & 1.27 \\
Online bidding / tendering & 2.31 & 1.21 \\
Private B2B exchange / Extranet - operated by your company for your suppliers & 1.87 & 1.19 \\
Private B2B exchange / Extranet - operated by your company for your customer(s) & 1.79 & 1.09 \\
Industry-sponsored e-marketplaces (e.g. Covisint) & 1.60 & 0.95 \\
Private B2B exchange / Extranet - operated by your supplier(s) & 1.54 & 0.77 \\
Public e-marketplaces (e.g. Global Healthcare Exchange) & 1.47 & 0.76 \\
Private B2B exchange / Extranet - operated by your customer(s) & 1.42 & 0.71 \\
\hline
\end{tabular}

${ }^{\dagger} 1=$ none, $2=$ slight, $3=$ moderate, $4=$ substantial, $5=$ extensive 
Table 4

Taxonomy of E-Business Technologies: Factor Analysis

\begin{tabular}{lccc}
\hline \multicolumn{1}{c}{ E-Business Technology Activity } & Factor 1 & Factor 2 & Factor 3 \\
\hline Electronic / online purchase order system & $\mathbf{. 7 6 2}$ & .190 & -.005 \\
Electronic / online supplier catalogue & $\mathbf{. 7 2 1}$ & .211 & .101 \\
Real-time electronic linkage with suppliers & $\mathbf{. 6 9 8}$ & .092 & .350 \\
Electronic data interchange (EDI) & $\mathbf{. 6 9 6}$ & .036 & .052 \\
Online bidding / tendering & .296 & $\mathbf{. 7 7 4}$ & .063 \\
Online reverse auction / e-auction & .296 & $\mathbf{. 7 5 0}$ & .016 \\
Industry-sponsored e-marketplaces (e.g. Covisint) & -.007 & $\mathbf{. 7 3 8}$ & .046 \\
Public e-marketplaces (e.g. Global Healthcare Exchange) & .048 & $\mathbf{. 7 1 8}$ & .263 \\
Private B2B exchange / Extranet - operated by your company for & .159 & .064 & $\mathbf{. 7 3 3}$ \\
your customer(s) & & & \\
Private B2B exchange / Extranet - operated by your company for & .282 & .097 & $\mathbf{. 7 2 7}$ \\
your suppliers & -.016 & -.004 & $\mathbf{. 7 1 4}$ \\
Private B2B exchange / Extranet - operated by your customer(s) & -.008 & .198 & $\mathbf{. 6 8 0}$ \\
Private B2B exchange / Extranet - operated by your supplier(s) & .008 \\
\hline
\end{tabular}

Table 5

Purchasing Team Usage: Rating Based on Team Composition

\begin{tabular}{lcc}
\hline \multicolumn{1}{c}{ Form of Team } & Mean $^{\dagger}$ & Std. Dev. \\
\hline cross-functional teams & 3.93 & 0.99 \\
commodity teams (purchasing personnel only) & 3.57 & 1.24 \\
purchasing councils (purchasing personnel only) & 2.83 & 1.30 \\
supplier councils (primarily key suppliers) & 2.11 & 1.10 \\
teams with external customers & 1.96 & 1.05 \\
teams with suppliers and external customers & 1.65 & 0.90 \\
\hline
\end{tabular}

${ }^{\dagger} 1=$ none, $2=$ slight, $3=$ moderate, $4=$ substantial, $5=$ extensive 
Table 6

Descriptive Statistics and Correlation Matrix

\begin{tabular}{|c|c|c|c|c|c|c|c|c|c|c|c|c|c|c|c|c|}
\hline & Variable & Mean & s.d. & 1 & 2 & 3 & 4 & 5 & 6 & 7 & 8 & 9 & 10 & 11 & 12 & 13 \\
\hline & Team usage & & & & & & & & & & & & & & & \\
\hline 1. & Internal Teams & 3.11 & 0.81 & & & & & & & & & & & & & \\
\hline \multirow[t]{2}{*}{2.} & Customer Teams & 1.80 & 0.91 & .26 & & & & & & & & & & & & \\
\hline & Firm characteristics & & & & & & & & & & & & & & & \\
\hline 3. & Sales & 3.51 & 1.17 & .28 & -.01 & & & & & & & & & & & \\
\hline \multirow[t]{2}{*}{4.} & Organizational Structure & 2.40 & 1.24 & -.05 & -.03 & -.10 & & & & & & & & & & \\
\hline & E-business technologies & & & & & & & & & & & & & & & \\
\hline 5. & Dyadic coordination & 2.91 & 0.89 & .36 & .15 & .34 & -.14 & & & & & & & & & \\
\hline 6. & Price determination & 1.97 & 0.82 & .44 & .23 & .39 & -.10 & .39 & & & & & & & & \\
\hline \multirow[t]{2}{*}{7.} & Private exchange & 1.65 & 0.70 & .36 & .22 & .13 & .07 & .33 & .26 & & & & & & & \\
\hline & Industry context & & & & & & & & & & & & & & & \\
\hline 8. & Discrete $^{\mathrm{a}, \mathrm{b}}$ & 0.27 & 0.45 & .15 & .12 & -.19 & .10 & -.07 & .00 & .16 & & & & & & \\
\hline 9. & Processing $^{\mathrm{a}, \mathrm{b}}$ & 0.33 & 0.47 & .06 & -.01 & .02 & -.02 & .05 & .15 & -.01 & -.43 & & & & & \\
\hline 10. & Low cap. services ${ }^{\mathrm{a}, \mathrm{b}}$ & 0.18 & 0.38 & -.11 & .03 & .04 & -.01 & .06 & -.22 & -.12 & -.28 & -.33 & & & & \\
\hline 11. & High cap. services ${ }^{\mathrm{a}, \mathrm{b}}$ & 0.19 & 0.39 & -.09 & -.14 & .16 & -.11 & .04 & .05 & -.07 & -.29 & -.34 & -.22 & & & \\
\hline \multirow[t]{2}{*}{12.} & Resource-Based $\mathrm{d}^{\mathrm{a}, \mathrm{b}}$ & 0.04 & 0.19 & -.10 & -.03 & -.04 & .08 & -.16 & -.02 & .04 & -.12 & -.13 & -.09 & -.09 & & \\
\hline & Financial performance & & & & & & & & & & & & & & & \\
\hline 13. & Return on Assets (ROA) (\%) & 0.69 & 0.06 & .11 & .02 & -.04 & -.01 & .11 & -.00 & .15 & .17 & -.10 & -.04 & -.16 & .11 & \\
\hline 14. & Return on Sales (ROS) (\%) & 1.40 & 0.09 & -.06 & -.06 & -.02 & .01 & .01 & -.10 & -.07 & .17 & -.05 & -.02 & -.10 & .00 & .47 \\
\hline
\end{tabular}

Notes

Correlations $\geq .16$ are significant at $p<.01 ; \geq .12$, at $p<.05$; all two-tailed tests

$\mathrm{N}=284$, except for measures of financial performance with $\mathrm{N}=196$.

${ }^{a}$ Dichotomous variable, coded as 1 if true, 0 otherwise. Spearman correlations are reported for these variables.

${ }^{\mathrm{b}}$ Industry classification: discrete manufacturing $=\mathrm{SIC}$ codes 25, 31, 34, 35, 36, 37, 38 and 39; processing $=20,24,26,27$,

28, 29, 30, 32 and 33; resource and construction $=10,12,13$ and 16; high capital-intensive service $=40,45,48,49,58$ and

75; low capital-intensive service $=42,47,61,63,64,70,73,78$ and 87. 
Table 7

Results of Tobit Regression Analysis: E-Business Technology Use

\begin{tabular}{|c|c|c|c|c|c|c|c|c|c|c|c|c|}
\hline \multirow[t]{2}{*}{ Independent Variables } & \multicolumn{4}{|c|}{ Dyadic Coordination } & \multicolumn{4}{|c|}{ Price Determination } & \multicolumn{4}{|c|}{ Private Exchange } \\
\hline & \multicolumn{2}{|c|}{ Model 1} & \multicolumn{2}{|c|}{ Model 2} & \multicolumn{2}{|c|}{ Model 3} & \multicolumn{2}{|c|}{ Model 4} & \multicolumn{2}{|c|}{ Model 5} & \multicolumn{2}{|c|}{ Model 6} \\
\hline Team usage & & & & & & & & & & & & \\
\hline Internal & $\begin{array}{r}0.306 \\
(0.064)\end{array}$ & $* *$ & $\begin{array}{r}0.298 \\
(0.065)\end{array}$ & $* *$ & $\begin{array}{r}0.331 \\
(0.062)\end{array}$ & $* *$ & $\begin{array}{r}0.336 \\
(0.062)\end{array}$ & $* *$ & $\begin{array}{r}0.313 \\
(0.063)\end{array}$ & $* *$ & $\begin{array}{r}0.315 \\
(0.064)\end{array}$ & $* *$ \\
\hline Customer & $\begin{array}{r}0.075 \\
(0.053)\end{array}$ & & $\begin{array}{r}0.072 \\
(0.053)\end{array}$ & & $\begin{array}{r}0.140 \\
(0.049)\end{array}$ & $* *$ & $\begin{array}{r}0.157 \\
(0.049)\end{array}$ & $* *$ & $\begin{array}{r}0.124 \\
(0.050)\end{array}$ & * & $\begin{array}{r}0.121 \\
(0.050)\end{array}$ & $*$ \\
\hline \multicolumn{13}{|l|}{ Industry context } \\
\hline Manufacturing & $\begin{array}{r}-0.157 \\
(0.101)\end{array}$ & & & & $\begin{array}{r}0.221 \\
(0.097)\end{array}$ & $*$ & & & $\begin{array}{r}0.118 \\
(0.098)\end{array}$ & & & \\
\hline Processing & & & $\begin{array}{r}0.088 \\
(0.123)\end{array}$ & & & & $\begin{array}{r}0.094 \\
(0.114)\end{array}$ & & & & $\begin{array}{r}-0.152 \\
(0.117)\end{array}$ & \\
\hline Resource & & & $\begin{array}{r}-0.448 \\
(0.266)\end{array}$ & $\dagger$ & & & $\begin{array}{r}0.132 \\
(0.246)\end{array}$ & & & & $\begin{array}{r}0.218 \\
(0.249)\end{array}$ & \\
\hline High capital-intensive services & & & $\begin{array}{r}0.099 \\
(0.148)\end{array}$ & & & & $\begin{array}{r}0.080 \\
(0.138)\end{array}$ & & & & $\begin{array}{r}-0.175 \\
(0.142)\end{array}$ & \\
\hline Low capital-intensive services & & & $\begin{array}{r}0.260 \\
(0.148)\end{array}$ & $\dagger$ & & & $\begin{array}{r}-0.417 \\
(0.142)\end{array}$ & $* *$ & & & $\begin{array}{r}-0.200 \\
(0.143)\end{array}$ & \\
\hline \multicolumn{13}{|l|}{ Firm characteristics } \\
\hline Organizational structure & $\begin{array}{r}-0.092 \\
(0.038)\end{array}$ & $*$ & $\begin{array}{r}-0.085 \\
(0.038)\end{array}$ & $*$ & $\begin{array}{r}-0.081 \\
(0.037)\end{array}$ & $*$ & $\begin{array}{r}-0.072 \\
(0.036)\end{array}$ & $*$ & $\begin{array}{r}0.050 \\
(0.037)\end{array}$ & & $\begin{array}{r}0.041 \\
(0.037)\end{array}$ & \\
\hline Firm size & $\begin{array}{r}0.191 \\
(0.043)\end{array}$ & $* *$ & $\begin{array}{r}0.190 \\
(0.043)\end{array}$ & $* *$ & $\begin{array}{r}0.259 \\
(0.041)\end{array}$ & $* *$ & $\begin{array}{r}0.245 \\
(0.041)\end{array}$ & $* *$ & $\begin{array}{r}0.033 \\
(0.041)\end{array}$ & & $\begin{array}{c}0.041 \\
(0.042)\end{array}$ & \\
\hline Constant & $\begin{array}{r}0.975 \\
(0.240)\end{array}$ & $* *$ & $\begin{array}{r}0.819 \\
(0.254)\end{array}$ & $* *$ & $\begin{array}{r}-0.705 \\
(0.244)\end{array}$ & $* *$ & $\begin{array}{r}-0.562 \\
(0.250)\end{array}$ & * & $\begin{array}{r}-0.407 \\
(0.242)\end{array}$ & $\dagger$ & $\begin{array}{r}-0.230 \\
(0.255)\end{array}$ & \\
\hline Log Likelihood & -333 & & -330 & & -284 & & -278 & & -263 & & -261 & \\
\hline
\end{tabular}

$\mathrm{N}=284 ;{ }^{\dagger} \mathrm{p}<0.10 ;{ }^{*} \mathrm{p}<0.05 ; * * \mathrm{p}<0.01 ;$ standard errors noted in brackets 
Table 8

Results of Regression Analysis: Firm Performance

\begin{tabular}{|c|c|c|c|c|}
\hline \multirow{2}{*}{$\begin{array}{l}\text { Independent Variables } \\
\text { E-business technologies }\end{array}$} & \multicolumn{2}{|c|}{$\begin{array}{c}\text { Return on } \\
\text { assets (ROA) } \\
\text { (percentage) }\end{array}$} & \multicolumn{2}{|c|}{$\begin{array}{c}\text { Return on } \\
\text { Sales (ROS) } \\
\text { (percentage) }\end{array}$} \\
\hline & & & & \\
\hline Dyadic coordination & $\begin{array}{r}1.12 \\
(0.523)\end{array}$ & $* *$ & $\begin{array}{r}1.62 \\
(0.687)\end{array}$ & $* *$ \\
\hline Price Determination & $\begin{array}{r}-0.392 \\
(0.581)\end{array}$ & & $\begin{array}{r}-0.546 \\
(0.763)\end{array}$ & \\
\hline Private Exchange & $\begin{array}{r}0.908 \\
(0.671)\end{array}$ & & $\begin{array}{r}-0.454 \\
(0.881)\end{array}$ & \\
\hline \multicolumn{5}{|l|}{ Team usage } \\
\hline Internal & $\begin{array}{r}0.540 \\
(0.607)\end{array}$ & & $\begin{array}{r}-1.27 \\
(0.798)\end{array}$ & \\
\hline Customer & $\begin{array}{r}-0.264 \\
(0.458)\end{array}$ & & $\begin{array}{r}0.077 \\
(0.602)\end{array}$ & \\
\hline \multicolumn{5}{|l|}{ Industry context } \\
\hline Processing & $\begin{array}{r}-2.58 \\
(1.05)\end{array}$ & $* *$ & $\begin{array}{r}-2.37 \\
(1.38)\end{array}$ & $\dagger$ \\
\hline Resource & $\begin{array}{l}0.921 \\
(2.02)\end{array}$ & & $\begin{array}{l}-1.71 \\
(2.65)\end{array}$ & \\
\hline High capital-intensive services & $\begin{array}{l}-3.71 \\
(1.22)\end{array}$ & $* *$ & $\begin{array}{r}-4.88 \\
(1.60)\end{array}$ & $* *$ \\
\hline Low capital-intensive services & $\begin{array}{l}-2.42 \\
(1.37)\end{array}$ & $* *$ & $\begin{array}{l}-6.00 \\
(1.80)\end{array}$ & $* *$ \\
\hline \multicolumn{5}{|l|}{ Firm characteristics } \\
\hline Organizational structure & $\begin{array}{r}-0.239 \\
(0.324)\end{array}$ & & $\begin{array}{r}-0.214 \\
(0.426)\end{array}$ & \\
\hline Firm size & $\begin{array}{r}-0.503 \\
(0.428)\end{array}$ & & $\begin{array}{r}0.150 \\
(0.562)\end{array}$ & \\
\hline Constant & $\begin{array}{r}-0.200 \\
(2.41)\end{array}$ & & $\begin{array}{r}4.47 \\
(3.17)\end{array}$ & \\
\hline $\mathrm{R}^{2}$ & 0.133 & & 0.096 & \\
\hline $\mathrm{F}$ & 2.50 & $* *$ & 1.72 & $\dagger$ \\
\hline
\end{tabular}

$\mathrm{N}=191 ;{ }^{\dagger} \mathrm{p}<0.10 ;{ }^{*} \mathrm{p}<0.05 ; * * \mathrm{p}<0.01$; standard errors noted in brackets 
Table 9

Case Studies

\begin{tabular}{|c|c|c|c|c|}
\hline & Site A & Site B & Site $\mathbf{C}$ & Site D \\
\hline $\begin{array}{l}\text { Primary } \\
\text { business }\end{array}$ & $\begin{array}{l}\text { Global manufacturer and distributor of } \\
\text { agriculture, construction, forestry, } \\
\text { commercial and consumer equipment }\end{array}$ & $\begin{array}{l}\text { Global provider of industrial automation } \\
\text { solutions }\end{array}$ & Producer of packaged consumer foods & Global provider of financial services \\
\hline Sales & \$20 billion & $\$ 5$ billion & $\$ 10$ billion & $\$ 30$ billion \\
\hline $\begin{array}{l}\text { Overview of } \\
\text { e-business } \\
\text { growth }\end{array}$ & $\begin{array}{l}\text { - Started in } 1994 \\
\text { - Large group of } 30 \text { people dedicated } \\
\text { to e-business } \\
\text { - Substantial investments in } \\
\text { technology for: ERP system, reverse } \\
\text { auctions and on-line invoicing, } \\
\text { project tracking, PO submissions, } \\
\text { supplier evaluation system. }\end{array}$ & $\begin{array}{l}\text { Recently started a major e-business } \\
\text { technology initiative that would: } \\
\text { create a centralized global database } \\
\text { (new ERP system) linking plants and } \\
\text { head office functions (e.g., supply), } \\
\text { reduce transaction costs by automating } \\
\text { processes, improve fulfillment speed, } \\
\text { assist with early supply and supplier } \\
\text { involvement in NPD and support a } \\
\text { new low cost country sourcing } \\
\text { initiative }\end{array}$ & $\begin{array}{l}\text { - An early SAP adopter and the purchasing } \\
\text { module was the first to be launched in the } \\
\text { company in } 1993 \text {. } \\
\text { - Cost reduction initiative as a result of } \\
\text { competition and margin erosion: major } \\
\text { waste reduction initiatives, improved } \\
\text { supplier lead times, and reduced purchased } \\
\text { SKUs and numbers of suppliers. } \\
\text { - Adopted "supply chain network" intranet } \\
\text { and "global supply extranet" to facilitate } \\
\text { information flow among supply chain } \\
\text { partners. Important customers had similar } \\
\text { initiatives (e.g., Wal-Mart) }\end{array}$ & $\begin{array}{l}\text { - New contracting system within last } \\
\text { five years supported by a centralized } \\
\text { database linked to financial systems } \\
\text { (e.g., accounts payable) allows } \\
\text { purchasing to collect data and lead } \\
\text { the sourcing/contracting process. } \\
\text { - Relies on the contracting/sourcing } \\
\text { process. CPO does not believe that } \\
\text { price determination technologies, } \\
\text { such as reverse auctions, fit with the } \\
\text { sourcing needs of the organization. } \\
\text { Prefers to invest time up-front } \\
\text { identifying needs and negotiations. }\end{array}$ \\
\hline $\begin{array}{l}\text { E-business } \\
\text { technology } \\
\text { use }\end{array}$ & $\begin{array}{l}\text { - High dyadic and price determination } \\
\text { - Low private exchange, with high use } \\
\text { of B2B exchange for suppliers }\end{array}$ & $\begin{array}{l}\text { - High dyadic and price determination } \\
\text { - Low private exchange }\end{array}$ & $\begin{array}{l}\text { - High dyadic and price determination } \\
\text { - High private exchange }\end{array}$ & $\begin{array}{l}\text { - Low dyadic and price determination } \\
\text { - High private exchange }\end{array}$ \\
\hline $\begin{array}{l}\text { Purchasing } \\
\text { team use }\end{array}$ & $\begin{array}{l}\text { - Low internal teams, with high use of } \\
\text { cross-functional teams } \\
\text { - High external teams }\end{array}$ & $\begin{array}{l}\text { - High internal teams } \\
\text { - Low external teams }\end{array}$ & $\begin{array}{l}\text { - Low internal teams, with high use of } \\
\text { cross-functional teams } \\
\text { - High external teams }\end{array}$ & $\begin{array}{l}\text { - High internal teams } \\
\text { - Low external teams }\end{array}$ \\
\hline $\begin{array}{l}\text { Motivation } \\
\text { for e- } \\
\text { business } \\
\text { technology }\end{array}$ & $\begin{array}{l}\text { - Cost reduction: Reduced transaction } \\
\text { costs and paper flow; support } \\
\text { supplier cost reduction initiatives } \\
\text { - Support strategic supplier } \\
\text { relationships in areas such as } \\
\text { involvement in new product } \\
\text { development (NPD). } \\
\text { - Planning and scheduling } \\
\end{array}$ & $\begin{array}{l}\text { - Spend analysis to identify cost } \\
\text { reduction opportunities across } \\
\text { business units. } \\
\text { - Reduce transaction costs and paper } \\
\text { flow }\end{array}$ & $\begin{array}{l}\text { - Frustration with inadequacies of } \\
\text { purchasing information system in early } \\
1990 \text { s. ERP system and the database that it } \\
\text { provided represented the primary e- } \\
\text { business technology in use at the company } \\
\text { - Supply chain integration } \\
\text { - Public exchanges used for agricultural } \\
\text { commodities }\end{array}$ & $\begin{array}{l}\text { - Moving transaction based processes } \\
\text { on-line using supplier portals. } \\
\text { - The organization is decentralized. } \\
\text { As a result the company uses e- } \\
\text { business technologies to simplify the } \\
\text { purchasing process, reduce } \\
\text { transaction costs and provide access } \\
\text { to users. }\end{array}$ \\
\hline $\begin{array}{l}\text { Motivation } \\
\text { for } \\
\text { purchasing } \\
\text { teams }\end{array}$ & $\begin{array}{l}\text { - Early supplier involvement in new } \\
\text { product development } \\
\text { - Cost reductions } \\
\text { - Supply chain integration and } \\
\text { information sharing with suppliers }\end{array}$ & $\begin{array}{l}\text { - Decentralized purchasing organization } \\
\text { resulted in creation of purchasing } \\
\text { councils } \\
\text { - Strategic sourcing used commodity } \\
\text { review teams for analysis and supplier } \\
\text { selection }\end{array}$ & $\begin{array}{l}\text { Director of sourcing operations worked } \\
\text { with cross-functional business unit teams } \\
\text { - Suppliers involved in NPD. Large } \\
\text { customers, such as Wal-Mart, also } \\
\text { participated but less frequently. }\end{array}$ & $\begin{array}{l}\text { - User engagement identified by the } \\
\text { CPO as the "key enabler for } \\
\text { success". Purchasing managers led } \\
\text { internal cross-functional teams. } \\
\text { - Suppliers engaged not up-front, only } \\
\text { after supplier selection. }\end{array}$ \\
\hline
\end{tabular}

